\title{
ASEAN's Preventive Diplomacy: What Roles for ASEAN in the South China Sea and the Rakhine State Issues?
}

\author{
Chheun Sokla \\ Central China Normal University (CCNU), Wuhan, China \\ Email: chheun.sokla@yahoo.com
}

How to cite this paper: Sokla, C. (2019). ASEAN's Preventive Diplomacy: What Roles for ASEAN in the South China Sea and the Rakhine State Issues? Open Journal of Political Science, 9, 434-457.

https://doi.org/10.4236/ojps.2019.92024

Received: March 30, 2019

Accepted: April 26, 2019

Published: April 29, 2019

Copyright $\odot 2019$ by author(s) and Scientific Research Publishing Inc. This work is licensed under the Creative Commons Attribution International License (CC BY 4.0).

http://creativecommons.org/licenses/by/4.0/

\begin{abstract}
The ASEAN's preventive diplomacy is the new phenomenon in the regional architecture concerning with the living and breathing modern miracle in ASEAN. It has been one of the most substantial scenarios for all nation states to utilize and benefit form in term of common national interest and to divert major conflicts in the area of peaceful cooperation. The challenging issue in ASEAN is triggering political and security regional become tremendous problem, so ASEAN wouldn't be ignorable and has to narrowly compromise those rising major issues, immediately. The South China Sea and the Rakhine State issues are the two common aspects undertaking and discussing urgently, and it will be an obstacle for ASEAN to move forward in ASEAN integration. The rises of China in Southeast Asia is also an area of concern for ASEAN's efforts at preventing conflict because the confidence building has illustrated little progress in last a few years-after the signed DOC in 2002 but the progressing negotiation on the $\mathrm{COC}$ is now difficult to be finalized. Whereas the Rakhine State issue in Myanmar is better understanding as the human rights concerns and ASEAN would appreciate the hard efforts between Myanmar and Bangladesh Governments. However, Rohingyas crisis is uncompromisingly facing crackdown by both parties on other matters. In this regard, ASEAN diplomacy is applied by its roles and encourages powerful actors to take action with regards to the signatory MoU between Myanmar Government, UNDP and UNHCR in 2018. Facilitating the process of the repatriation of the displaced persons, is a positive measure to achieve solution for the people in Rakhine State. These sensitive issues are struggling ASEAN to quickly move on to the sustainable development, and also concern to all ASEAN partners especially the United Nations and the United States of America.
\end{abstract}

\section{Keywords}

Diplomacy, Preventive Diplomacy, ASEAN, South China Sea, Rakhine State 


\section{Introduction}

In the context of multi-polarity system, states need balance of powers to strengthen their national interest and to safeguard their territory and sovereignty in term of political transformation. In the meanwhile, the Association of Southeast Asian Nations (ASEAN) was a successful regional organization, which is located in Southeast Asia region within ten member states-Brunei Darussalam, the Kingdom of Cambodia, the Republic of Indonesia, the Lao People's Democratic Republic, Malaysia, the Union of Myanmar, the Republic of the Philippines, the Republic of Singapore, the Kingdom of Thailand, and the Socialist Republic of Viet Nam (ASEAN Charter, 2011). First, ASEAN had only five members that was well recognized as the five founding fathers namely Indonesia, Malaysia, the Philippines, Singapore, and Thailand, and officially established in Bangkok on 8th August 1967 or called the Bangkok Declaration. On 8th August every year, ASEAN Member States (AMS) celebrated the ASEAN Day-in order to maintain the regional solidarity and cooperation, towards peace, progress, prosperity in the region, and consciousness of increasingly interdependence in the world, promote and protect human rights and fundamental freedom, social justice and economic well-being, good understanding, and good neighborliness, and especially to ensure stability and security from external interference (Kishore \& Jeffery, 2017). ASEAN has three main pillars such as ASEAN's Political-Security Community, ASEAN Economic Community, and ASEAN Socio-Cultural Community. ASEAN therefore is strengthening its influences to all major power states according to its political, economic and socio-cultural model, but the political-security pillar was prioritized as extremely sensitive institution towards the development of the world political and geopolitical revolution especially in Asia-Pacific. In fact, even ASEAN is committed to being safe and high security in Southeast Asia, but conflicts or disputes sometimes happened between bordering countries in the same bloc because of their national interests and nationalism. Thus, ASEAN has to take pro-actions and actively involved with those activities by coming up with diplomacy and ASEAN's dispute mechanism. Dispute is huge obstacle and happened in different type of forms in which every country is debatable on different topic and continuously joined with regional and international organization in order to prevent its widespread into violence or wars (Mitchell, 2016).

Actually, ASEAN's preventive diplomacy was firstly defined since 1967 (Kevin \& Rosario, 2017). Later than in 2007, the combination of norms and principles started officially establishment declared as the legal instrument called ASEAN Charter, and the clearly purposes and principles could be trusted as guideline and roadmap towards ASEAN Community. Article 25, Establishment of Disputes Settlement Mechanism, of the ASEAN Charter expressed the use of the preventive diplomacy which said that how disputes should be solved by different mechanism. Linked with these characteristics, in Article 32 "ensure an effective and timely response to urgent issues or crisis situations affecting ASEAN, in- 
cluding providing its good offices and such other arrangement to immediately address these concerns", emphasized the role of the ASEAN Chair to address all kinds of issues through diplomacy and diplomacy here related to the conflicts prevention. The Chapter 8 of the ASEAN Charter, the settlement of disputes have been a very specific for ASEAN to solve conflicts and should be considered as the first option for states to prevent violence and conflicts due to the existing mechanism. Leading many elements the "ASEAN Way" is pragmatism of decision making based on consultation to reach a peak called "Consensus". Dialogues and consultations are the compromising-led to foster parties of a willingness to understand situation and accepted an equilibrium point, to halt the influences of superpower to smaller states and allow smaller states to articulate their position (Quilop, 2002).

The conflicts resolution in ASEAN is not only enshrined in the ASEAN Charter but also mentioned in the ASEAN Protocol on Enhanced Dispute Settlement Mechanism-this protocol is made to be more specific on the disputes settlement that goes along with the article 20 and 23 of the ASEAN Charter. The article 3 of this protocol is described about the Consultation, whereas the article 4 requires that "Member States which are parties to a dispute may at any time agree to good offices, conciliation or mediation" (ASEAN Protocol on Enhanced Dispute Settlement Mechanism, 2012). Of course, the reflection of this protocol would be assisted ASEAN members to settle a dispute. However, before these three procedures implemented, the diplomacy roles must be pre-practiced, so the preventive diplomacy has been applied.

In the international arena, diverting conflicts mechanisms have always been practicing not only negotiation, conciliation but also the most substantial is the preventive diplomacy now. Many disputes were taken places and driven much attention in Asia-Pacific nowadays, and considering as seriously issues which caused numerous people to become starvation, displaceability, violentness, and lacking of human rights. These challenge issues are enduring states more concerns to be used of force and threat, and could be armed raises. The two following sensitive issues are now facing in ASEAN like the South China Sea and the Rakhine State. These issues, therefore, would be resulted by utilizing the preventive diplomacy in which evoked in ASEAN, and how ASEAN prevent both issues in term of the preventive diplomacy. Thus, the following ideals could be mainstreamed to researchers be acknowledgeable, and how quality of preventive diplomacy in ASEAN, what territory conflicts been successfully solved, and which country used this strategy to war prevention.

\section{Defining Diplomacy}

The diplomatic relations in the 21st century is extremely noteworthy regarding the political transformations and global issues. In the diplomatic ties, the Westphalia Treaty was the most famous document that recognized as the starting point of state relations and also commonly recorded as the modern states system 
in 1648 in order to encourage states to develop more interconnectedness through diplomacy and militarization (Basu, 2012). Noticeably, diplomacy and international relations are used tangibly and have a long history to known as political diplomacy which firstly founded at the University College of Wales in 1919 in England (Basu, 2012). Based on demanding of national interest and different geographical condition in term of political, economic and socio-cultural, the diplomatic relations have been workout in variety of categories, furthermore, many international organizations, regional organizations, and non-governmental organizations or could be non-state actors have formulated such as the United Nations, International Monetary Fund, Asia-Pacific Economic Forum, European Union, Group of 20, and ASEAN, etc.

Regarding to the above-mentioned organizations, tactical diplomatic ties subsequently uses to make a good relationship and also to avoid the conflict occur unintentionally. In this connection, diplomacy has specifically to move forward its direction into different types of sectors due to the variety of circumstances in relations. Diplomacy has given many definitions by difference scholars or books, so it refers to a code of honor, a standard to test things, and it has not obligation relations to the moral code and its standard has not necessary to respect with the correctness of related causes (Sharp, 2009). In other words, diplomacy also defined as the control of relationship in the good office which the methodology of these relations such as the business relations or the tactics of diplomat which are familiar and managed by ambassadors and envoys, or another definition could be suggested as the official relations between an independent state and independent state in order to expend their relations to conduct of political, economic, cultural, trade, foreign investment, tourism, and other sectors, by peaceful means (Basu, 2012). Diplomacy also related to the process of state and state's interaction through the practicing of their foreign policy by ministers, ambassadors, envoys or spokesperson, and could be the procedure of disputes settlement (Martin, Terry, \& Steven, 2008). In addition, diplomacy is the means by state's communication in the world by its affairs in ways to maintain peaceful relations and to benefit national interest throughout the diplomatic services of respective countries abroad especially concerning to the promotion of political, economic, cultural and following the international system based on the promotion and protection of human rights or peaceful dispute settlement (Bern, 2008).

\section{What Is Preventive Diplomacy?}

Diplomacy generated as very overall which isn't specific to an area of field. However, diplomacy could be defined as different types and functions such as political diplomacy, military diplomacy, economic diplomacy or diplomacy of development, cultural diplomacy, and other forms of diplomacy (Basu, 2012). Taking into this account, the preventive diplomacy is often show off when one country influences its pose to restrain on other's military or economy. And what is the preventive diplomacy? The founder of the preventive diplomacy was in- 
troduced by Secretary-General Dag Hammarskjöld in the mid-1950, then in early1990 was proposed by Boutros Boutros-Ghali, Secretary General of the United Nations, which recognized as the conflicts prevention toolkit (Mancini, 2011). After that, the concept of the preventive diplomacy was firstly again officially denouncing by the UN Secretary-General Boutros-Ghali at his publication on an agenda namely, An Agenda for Peace, which emphasized as "action to prevent disputes from arising between the parties, to prevent existing disputes from escalating into conflicts, and to limit the spread of the latter when they occur" (Yuzawa, 2006). The term preventive diplomacy is defined and given different definitions due to scholars or authors. In this regard, the preventive diplomacy has also been produced as an activity to halt the armed raise or conflicts of states before interwar situations or violence are subjective of the discussion (Zyck \& Muggah, 2012). Its definition also refers to ceasing tensions or diplomacy tactics which will be resulted in violence or wartime, and the preventive diplomacy could be played as many kinds of escalations including negotiation tactics, legal suggestions, and inquiry missions (Müllerleile, n.d.). Of course, the preventive diplomacy in international system found in the article 33 of the United Nations Charter, which was clarified the process of regional institutions to prevent disputes from arising parties, and also to prevent the existing disputes to be more peace and security regarding the deterrence or the economic sanction (Ralf \& See, 2009). Many concepts of preventive diplomacy have been raised, and the preventive diplomacy specifically defined as the action taken as diplomatic at any possibility utilization, and it is now very popular method to conflicts resolution mechanism (Hammarskjöld, 2011). According to Ralf E. \& See S. T., 2009, the preventive diplomacy approach appeared before conflicts outbreak that was meant the implementation of the preventive diplomacy varies from stage to stage, and it could be separated into three dimensions. First, early on, which practiced on basis sources of conflicts, and second is focused on preventing dispute that escalating into violence, and the third is the expansion of violence that could be resulted into wars. Preventive Diplomacy is also described as non-coercive-not military action or use of force-by individuals, governments, organizations, international institutions, and through all parties directly involved, in order to prevent disputes that could be arisen between or among parties, to divert the existing disputes from measuring into violence. Its meaning is explained not only in political and security but also workout with the whole range of economic and others, also; however, military is excluded (Cossa, 2002).

Specifically, the preventive diplomacy could be grounded in ASEAN as well, which called on to narrow the roles of outsider parties by reinforcing ASEAN Centrality of non-interference to ASEAN Member States-the preventive diplomacy used in the ASEAN Regional Forum, consequently, defined as political action or diplomatic services compromised by states to prevent disputes or conflicts which caused to threat regional peace and stability, and could be diverted those conflicts that escalated into armed raises or state's military confrontation especially avoid the impact of such disputes (Mancini, 2011). In this connection, 
the preventive diplomacy often plays role as conflicts resolution by peaceful means not only in the United Nations but also in other regional organization especially in ASEAN, which commonly appeared in the ASEAN Regional Forum's talks (ARF). In 1996, the ARF discussed on the Taiwan Strait Crisis that China exercised series of missile tests in the water surrounding Taiwan during the presidential election which led the United States to deter China's actions, and at the same time, the role of the ARF had been implemented by providing a dialogue platform between the United States and China (Ralf \& See, 2009). Another example is currently mentioned in the Chairman's Statement of the 25th ASEAN Regional Forum, which ministers underscored the significant satisfaction and progress role of the ARF in contributing political and security dialogue and cooperation including promoting confidence building and preventive diplomacy, and the key stability is to enhancing efforts by implementing the principles stipulated in the ARF Preventive Diplomacy Work Plan (ASEAN, Chairman's Statement of the 25th ASEAN Regional Forum, 2018). In addition, this statement highlighted positive progressing on the South China Sea and the Code of Conduct, welcomed Joint Statement signed between US President Donald Trump and Chairman Kim, and also noted on the humanitarian situation in Rakhine State by reaching an arrangement on return of displaced person between Myanmar and Bangladesh Government. These challenge issues were discussed under the ASEAN Chair by Singapore in the ARF, therefore, the roles of preventive diplomacy were implemented to reiterate and enhance positive developments and co-existent among ARF participants, including through continued constructive dialogue on issues of common interest and concern.

\section{The Concepts of ASEAN's Preventive Diplomacy}

ASEAN's diplomacy was found in 1967 or could be known as the Bangkok Declaration, and its diplomacy focused on the establishment of sovereign equality and the exercise of freedom to the avoidance of wars at all causes (Kevin \& Rosariom, 2017). In addition, diplomacy is the negotiation, and the negotiation in ASEAN is based on consensus, which is defined as the ASEAN Way, to invest on building the communities and sharing norms to the ten ASEAN countries and international institutions (ASEAN Charter, 2011).

ASEAN has maybe over 640 million people living with diversity of cultural, religious, but this key actor had been remarkable progressing over 50 years in keeping peace, security, prosperity, and harmony (Kishore \& Jeffery, 2017). To go forward and towards building peace and security, the preventive diplomacy has been used to avoid dispute or conflict in ASEAN, for example. A key dispute settlement that states always utilized to keep peace and prevent concerned tension in the areas of issues was the ASEAN Way. This regional organization has successfully made its fabulous roles as enshrined in the ASEAN Charter to maintain and enhance peace, security and stability, and to enhance regional resilient by promoting greater political, economic and socio-cultural cooperation in the region (ASEAN Charter, 2011). ASEAN countries are located in the same re- 
gion, and some member states-Myanmar, Laos, Viet Nam, Cambodia, Thailand, Malaysia, and Singapore are bordering, so territory conflict either land or sea will be happened. To divert these possibility conflicts in ASEAN, the preventive diplomacy plays as an active role to conciliate the dispute parties to attach with positive co-existent and converted unpredictable tension into peaceful negotiations.

The best example of the preventive diplomacy is the territorial conflict between Cambodia-Thailand over Preah Vihear temple which located in the boarder of Cambodia and Thailand. Preah Vihear, a temple built in the 11th century. In 1959, dispute was referred to the International Court of Justice (ICJ) then the ICJ ruled the temple to Cambodia in 1962 (Keating, 2011). Thailand agreed over Cambodia's Preah Vihear temple; however, land surrounding the temple acquires conflicts. Then Cambodia applied Preah Vihear temple complex to be list as a UN Education, Scientific and Cultural Organization (UNESCO) World Heritage site in 2007. Thailand side objected and both parties moved troops into and closer to the disputed area which caused people killed and thousands were displaced. Anyway, both countries continued to cooperate within the framework of ASEAN and, more specifically, allow ASEAN appointed observers to have access to the provisional demilitarized zone. Both sides avoided any action which might aggravate or extend the dispute before the court or make it more difficult to resolve, so ASEAN encouraged dispute parties to resolve the situation peacefully through effective dialogue and continued to cooperate with this organization, in this regard (Kesavapany, 2011). Through the ASEAN-led mechanism, the border fighting between Cambodia-Thailand troops stopped because of the intervention of ASEAN's preventive diplomacy. The dispute went along with Indonesia's ASEAN Chairmanship and with the Secretary General of ASEAN was Dr. Surin Pitsuwan, Thailand nationality (ASEAN Secretariat, 2011). The diplomatic efforts would be very helpful the two sides reach at a temporary solution and let bilateral mechanisms to cherish their objectives of border delineation-general peace in the areas shown off as ASEAN's preventive diplomacy. ASEAN implemented its own mechanism as appeared in article 22-28 in the ASEAN Charter to settle the dispute by providing good office, conciliation and mediation (ASEAN Charter, 2011). In this regard, the preventive diplomacy intervened this dispute through Indonesia as chairman, called Cambodia and Thailand to exercise self-refrain from violence and bring the solution of the ongoing conflict on negotiation table. This mechanism couldn't be effectively solved; however, it reduced and deterred tension in the area of conflict become positive development avoid military fighting, and also halt the widespread of the armed raise or armed confrontation, therefore, the effective of the preventive diplomacy showed off by encouraging the two parties to respect by implementing dispute settlement mechanism under the international laws. Finally, Cambodia-Thailand's option was decided to the International Court of Justice (ICJ) under United Nations' umbrella to be judicial; as a result, the Preah Vihear temple and the territory surrounding were officially ruled by Cambodia 
in 2013 (UN News, 2013).

ASEAN has so many meetings a year to deal with the cross cutting issues and also strongly implement its ways and principles as enshrined in the ASEAN Charter to achieve along with the ASEAN 2025: Forging Ahead Together. In order to achieve those principles, ASEAN has been implementing the ASEAN Centrality based on consensus to make a right decision on ASEAN Declarations, Chairman's Statements, Joint Communiques, and Press Statements or other ASEAN documentations. ASEAN's decision making based on consultation and consensus also considered as the preventive diplomacy because before making any decision on concern issues regarding the conflicts or effects national interest of AMS, ASEAN has to absolutely compromise those impacts interest from the Joint Working Groups (JWG) meetings to the Senior Official Meetings (SOM) or could be Ministers level. ASEAN launched many important entities in order to prevent conflicts such as ASEAN Regional Forum (ARF), East Asia Summit (EAS), as well as ASEAN plus the Three (APT) (Ralf \& See, 2009). These forums are triggering ASEAN to get involved with the most rising power states both military and economic to come up with and discuss mostly on security, economic and other fields' cooperation, and therefore, the preventive diplomacy will be functioned to be addressed the challenge issues in the region.

ASEAN Family of Regional Security Institutions: Figure 1 shows that ASEAN is at the center of the regional security institutions which the ARF established in 1994, and the ASEAN Plus Three's cooperation in 1997, and the last security institution was the East Asia Summit in 2005 (Friedrichs, 2012).

\subsection{The ARF's Preventive Diplomacy}

Before the ARF established in 1990, some ASEAN members and dialogue partners proposed different views on the objectives of ARF. Japan looks so much active to seek specifically used the ARF in promoting security and take the ARF to be productive approach to the common preventive diplomacy agenda, which supported by the United States, Canada, and Australia, to use the ARF as conflict prevention. Whereas, Thailand and the Philippines pointed that the conflict prevention would be solved but must be based on ASEAN principles of noninterference and consensus (Yuzawa, 2006). Then in 1994, the ARF was officially established in objectives "to foster constructive dialogue and consultation on political and security issues of common interest and concern; and to make significant contributions to efforts towards confidence-building and preventive diplomacy in the Asia-Pacific region", and comprises 27 members included ASEAN countries plus Australia, Bangladesh, Canada, China, North Korea, European Union, India, Japan, Mongolia, New Zealand, Pakistan, Papua New Guinea, South Korea, Russia, Sri Lanka, Timor-Leste, and the United States (Asean Regional Forum, n.d.). The ARF is very controversial concepts. Anyway, the cornerstone definition of the preventive diplomacy as enshrined in the concept and principle of the ARF defined as political action and diplomatic ties between nation states which all relevant parties agreed to directly get involved in term of 


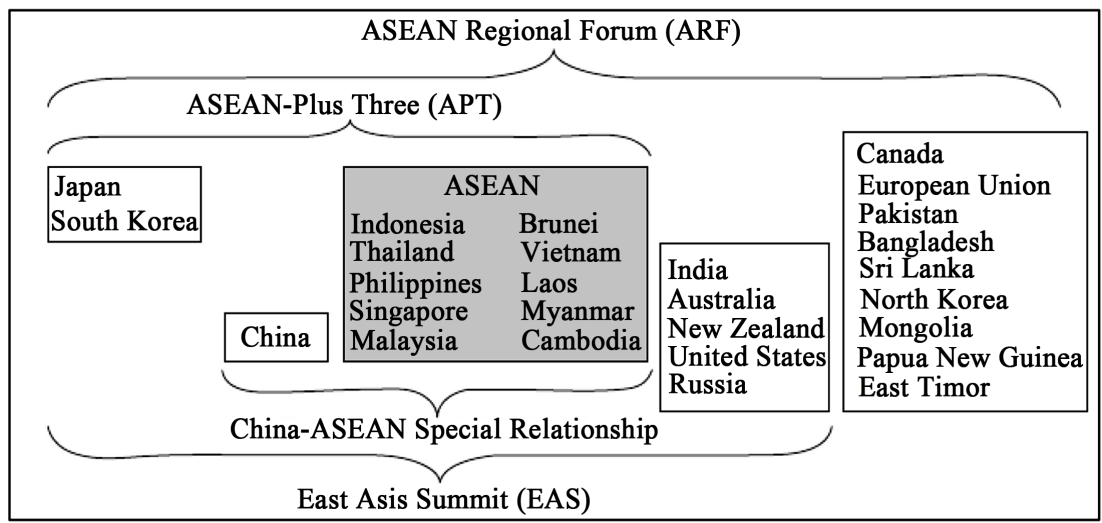

Figure 1. ASEAN family of regional security institutions.

diverting conflicts and disputes that could be violent to what extent and also invasion to course instability in the region, avoiding conflicts and disputes that in escalating into armed threat and state's confrontation, and compromising high effect of conflicts and disputes in the entire region (Quilop, 2002). According to the paper on Concept and Principles of Preventive Diplomacy adopted by the ministers of the ARF states, preventive diplomacy is:

[ARF] consensual diplomatic and political action taken by sovereign states with the consent of all directly involved parties: to help prevent disputes and conflicts from arising between states that could potentially pose a threat to regional peace and stability; to help prevent such disputes and conflicts from escalating into armed confrontation; and to help minimize the impact of such disputes and conflicts on the region (2001 ASEAN Regional Forum, Concept and Principles of Preventive Diplomacy, 2001).

The ARF is the most significant forum for security dialogue in Asia, which are drawing much on the preventive diplomacy to divert conflicts by promoting an effective discussion and open dialogue on political and security in the region, especially in Asia Pacific. Doing so, ARF now is a key forum to the consultation in the agenda of preventive diplomacy on security dialogue by complementing the previous bilateral alliances and dialogue partners that members could be exchanged views regarding the current regional security issues and further strengthen to develop a productive measure to uphold peace and security in the region.

In ASEAN, diplomacy mechanism would be a strongly approach in persuading all leaders in other parts of the world to face-to-face indebt discussions on political and security transformations which mostly strike to engage stability and peaceful means. Anyway, in 2017 when the Philippines as the chairmanship of ASEAN, the ASEAN Foreign Ministers appreciated the activities of the preventive diplomacy in accordance with the strengthening of building confidence to advance practice towards conflicts prevention evolving regional security architecture in the Asia Pacific (ASEAN, Joint Communique of the 50th ASEAN Foreign Ministers' Meeting, 2017). Asai and Manalo said that the Philippines would not take the South China Sea arbitration award as the topic of discussion at the 
ASEAN meeting when it assumes the rotating chairmanship of ASEAN.

The ARF Concept and Principles of Preventive Diplomacy has eight main keys aspects that discuss at the Council for Security Cooperation in the Asia Pacific (CSCAP) - the CSCAP provides informal mechanism for officials as well as scholars and others to discourse political and security issues that offer policy recommendations to intergovernmental organization bodies, non-state actors and establishes the connection with the rest of the world to give-and-take information, experiences in collaboration of regional political and security cooperation. The CACAP is convened by a member from ASEAN Member Committee co-chair with a member from a non-ASEAN Member Committee (CSCAP, 1999-2018). In this regard, the following are the summary of eight principles of the preventive diplomacy in the ARF:

1) "Diplomacy relies on diplomatic and peaceful methods,

2) Non-coercive;

3) Preventive rather than curative;

4) Trust and confidence;

5) Operates on the basis of consultation and consensus;

6) Voluntary only the request of all the parties directly involved in the dispute;

7) Applied to conflicts between and among states;

8) Conducted in accordance with basic principles of international laws (2001 ASEAN Regional Forum, Concept and Principles of Preventive Diplomacy, 2001)".

The above mentioned principles of the preventive diplomacy were agreed by the ministers on the definition and common understanding that would be necessary for further strengthening the progress on the development of the preventive diplomacy within the ARF. To be effective implementation on these principles, it must be focused on regional which covering comprehensive analysis on domestic, and the globalization features of conflict are investigating on political factors, social, economic, strategic underlying (Quilop, 2002). In this regard, security forum proposed by ASEAN is not only the ARF but also the EAS as well.

\subsection{The EAS's Preventive Diplomacy}

The EAS, particularly, typically a very substantial ASEAN leaders' summit on key aspects of political and security strategic dialogue and cooperation and also in the area of talks on economic challenging in Indo-Pacific in order to a closer regional cooperation (East Asia Summit Factsheet, 2018). The EAS's inaugural was in 2015, Malaysia. The EAS Summit consists of 13 member countries, namely 13 countries in the region (10 ASEAN countries, China, Japan and Korea) and 5 observers, namely 5 foreign countries (the United States, Australia, New Zealand, Russia and India). Recently, at the 8th EAS foreign ministers' summit on 4 August 2018, many challenge facing issues of political and security were discussed such as the South China Sea, the Korean Peninsula, Cyber Security and Maritime Cooperation, the Rakhine State, Combatting Violent Extremism, and also Radicalization and Terrorism (East Asia Summit Factsheet, n.d.). 
These interesting topics' discussion emphasized that the preventive diplomacy took place and further strengthen to prevent major disputes and conflicts that would be minimized tension of those issues on the rising of armed threat.

Therefore, disputes parties could be used the preventive diplomacy to enhance a productive negotiation by peaceful means, and also raising up together to deal with the best solution in the context of diplomacy ties. The globalization would be a major challenge issue regarding the economic growth in the East Asia especially concerns with competitiveness on trade which caused to threaten of regional security challenges. Of cause, the territorial disputes, for example, the South China South, the Korean Peninsula, are the long-standing conflicts which could be risked to presence of war; therefore, the conflicts prevention should be prioritized as disputes settlement. Referring to the security challenges and the roles of the EAS as well as the ASEAN regional security, this potential summit would be discussed on some common issues such as; conflicts resolution, managing peaceful dialogue, buttressing regime stability, and also improving interstates trust (Friedrichs, 2012).

As the EAS functioning on many great opportunities, so the problem solving as diplomatic means is taking much interaction to sharpen conflict resolution through diplomatic tactical in achieving the win-win situation. Not only regional security challenge and promoting peace, stability and prosperity but also remains as the center to advance dialogue and ensure strongly cooperation on summit with government leaders which emphasized that the EAS is key leader's gathering including some economic and military countries like the United States, China, and Japan; moreover, the EAS, of course, recognized as the center of ASEAN and ASEAN's mechanism on disputes settlement has been applied (NICK, 2017). In fact, the EAS leaders were taking much concern on the international issues and encourage dispute parties to build trust and confidence by partnering with respecting international law and find the best peaceful resolution through diplomacy ties; and for example, the EAS leaders persuaded China and the claimant states on the South China Seato further enhance the capacity of mutual trust and confidence in conducting of activities attached the with the United Nations Convention on the Law of the Sea (UNCLOS) in 1982 and international laws (ASEAN, Chairman's Statement of the 13th East Asia Summit, 2018). These approaches reflect the ASEAN's preventive diplomacy following by in-depth discussion of the forum along with strongly coordination of ASEAN.

The EAS is playing to facilitate with all relevant stakeholders to come up with dialogue cooperation by mutually understanding aiming to discover peace, security, stability, prosperity, and harmony region. Another milestone approaches on conflicts prevention must to mainstream the co-existent mechanism of ASEAN by round table discussion between ASEAN and its strategic partnership-China, Japan, and the Republic of Korea (ROK), which defined as the APT.

\subsection{The APT's Preventive Diplomacy}

At the sidelines of the 2nd ASEAN Informal Summit in Malaysia, ASEAN Lead- 
ers and China, Japan, and the ROK issued an Informal Summit to discuss about the APT cooperation process in December 1997; in the meanwhile, its ultimately progressing enhanced officially the APT Summit in 1999 when a Joint Statement East Asia Cooperation issued by leaders in order to strengthen and deepen cooperation in political, economic, socio-cultural, and others (ASEAN Secretariat, Overview of ASEAN plus Three Cooperation, 2018). Particularly, the APT seriously gets involved in deeper economic integration in East Asian not specifically on trade talks but also as a forum of exchange views on geopolitical and globalization issues. China, Japan and the ROK are core partners to transfer goods and services to ASEAN, thus, the challenge issues would be critically approached based on unpredictable national interest which prioritized as state's foreign policy. These above three countries are the major economic power in East Asia-China is the second largest economic in the world and also rising its relations with all countries especially with the Southeast Asia. In this regard, the APT's platform is very precisely opportunity to enhance and engage in political approach through diplomacy ties and could be used the preventive diplomacy in case of the widespread violence to be subject debatable.

In 2018, the APT leaders appreciated the Inter-Korea Summits which was held on 28 April, 26 May, and 18-20 September, and also the Kim-Trump Summit on 12 June-the Singapore Summit between the United States and the Democratic's People Republic of Korea. In this connection, the APT's diplomacy welcomed and encouraged all concerned parties to closely work together towards peace building and stability in the region through the pragmatic of agreed statements including the international community's instruments (ASEAN, Chairman's Statement of the 21st ASEAN plus Three Summit, 2018). Referring to the tensions of conflicts resolution, the East Asia Forum made a significantly progressed on working through preventive diplomacy of powerful politics and economics leaders which presence by the United States and China. The APT Summit always convened to be characterized and implemented the strategic and comprehensive approaches to inspire mutual trust cooperation by avoiding conflicts. Take into account, diplomacy ties is driven to building peace, security, and made the East Asia community.

These entities-ARF, EAS, and APT-always convened activities to avoid conflicts and to mainstreaming the values and norms of international laws to all relevant stakeholders and also encourage dispute parties to find solutions by respecting to the international laws and dispute settlement according to the international norms and systems and try to use the preventive diplomacy as well if it worked out.

\section{Applied ASEAN's Preventive Diplomacy in the South China Sea (SCS)}

Over the course of the past 15 years, relationship between China and ASEAN have been noticeably progressing in term of geopolitical turned. Based on the agenda of the high-level discussions or the ASEAN's Meetings and Related 
Meetings, geopolitical in the region has been discussing in almost agendas. China has many concern issues with bordering countries both land and sea. Rising major discussions in political situation in the SCS has been very popular topic for super power states, the United States, and claimant states. The SCS has been taken seriously issues for China as well as an international political concern which was the confrontation between China and some Southeast Asia countries. Itssea bordered was located by the north of China, the east by the Philippines, Malaysia, and Brunei, and the west by Vietnam including some parts on the south by Indonesia and Malaysia, which contained by more than 200 disparate islands and the most important such as the Paratas Islands, the Paracel Islands, the Maccles field Bank, the Scarborough Shoal, and the Spratly Islands in the south (Gu, n.d.). The SCS was the third largest marginal sea that known as different kind of energy resources like combustible ice, natural gas, and oil, and also the most potential area for fisheries and international transportation. According to the benefits of the SCS, the dispute settlement between China and the claimant states were complicated task to solve even it's intervened by third parties or international organization. Anyway, a kindly cooperation between ASEAN-China made this situation seriously well-released a productive environment because many parties of the dispute are AMS; and taking into this account, ASEAN has been trying to promote a peaceful atmosphere for SCS's dispute parties through ASEAN's dispute settlement called preventive diplomacy which ASEAN leaders currently discussed at the 13th EAS in Singapore (ASEAN, Chairman's Statement of the 21st ASEAN plus Three Summit, 2018).

Keeping this situation silently and positive progressing, ASEAN's preventive diplomacy had been actively implementing under ASEAN' umbrella to negotiate and between China and claimant states., Thus, China and ASEAN signed the ASEAN-China Declaration on the Conduct of Parties in the South China Sea (DOC) in Phnom Penh, Cambodia, on 4 November 2002, which reflected the role of the ASEAN's preventive diplomacy regarding the development on the SCS issues (Breckon, n.d.). This declaration signed by the Foreign Ministers of AMS and H.E. Wang Yi, Special Envoy and Vice-Minister of Foreign Affairs of China, and the DOC aims to confine the status que in the SCS to be silent and also to avoid the use of force and threat by dispute parties (ASEAN, The Declaration on the Conduct of Parties in the South China Sea (DOC), 2002). Indeed, China gained beneficially significantly on the DOC made by ASEAN's preventive diplomacy in terms of its diplomatic relations with AMS. The DOC was an important tool for China to conduct the situation in the SCS remained stable and forwards to negotiate with the claimant states, and also as a key to implement and further strengthening in positive means on the development of the SCS issues.

ASEAN issued an ASEAN's Six-Points Principles on the SCS on 20 July 2012, in Phnom Penh, which reiterated and reaffirmed the commitment of AMS and China to:

1) "The full implementation of the Declaration on the Conduct of Parties in 
the South China Sea (2002);

2) The Guidelines for the Implementation of the Declaration on the Conduct of Parties in the South China Sea (2011);

3) The early conclusion of a Regional Code of Conduct in the South China Sea;

4) The full respect of the universally recognized principles of International Law, including the 1982 United Nations Convention on the Law of the Sea (UNCLOS);

5) The continued exercise of self-restraint and non-use of force by all parties, and

6) The peaceful resolution of disputes, in accordance with universally recognized principles of International Law, including the 1982 UNCLOS" (Thayer, 2013).

To continue stopping the increased tension on the SCS, the ASEAN Post Ministerial Conference (PMC) +1 Session with China, on 30 June 2013 in Brunei Darussalam, the ministers agreed to be taken to establish an Eminent Persons and Experts Group (EPEG) and other mechanisms to provide support to the above official consultations, in order to resolve and ability to make the SCS become an area of peace, friendship and cooperation (ASEAN, Chairman's Statement of the ASEAN Post Ministerial Conference (PMC) 10+1 Sessions with the Dialogue Partners, 2013). Moreover, at the 16th ASEAN-China Summit, the ASEAN-China leaders also looked forward to the development of hotline communications in order to respond expeditiously to the situations at sea, including search and rescue of persons and vessels in distress and leaders agreed to promote trust, build confidence, and encourage concerned parties to prevent incidents at the SCS (ASEAN, Chairman's Statement of the 16th ASEAN-China Summit, 2013). The preponderance power of ASEAN-China is reaffirmed the importance of maintaining peace, stability and maritime security in the region and further stressed the importance of the positive evolution of the DOC. These two parties continued their utmost contributions to fully and effectively implement the DOC, to build trust and confidence in order to enhance maritime security, and encourage the sovereign states directly concerned to resolve their dispute by peaceful means through friendly consultations and negotiations, in accordance with the universally recognized principles of international law, including the 1982 UNCLOS, without resorting to the threat or use of force, while exercising self-restraint in the conduct of activities that would complicate or escalate disputes and affect peace and stability (ASEAN, Chairman's Statement of the 17th ASEAN-China Summit, 2014). The dialogues and cooperation between ASEAN-China on the SCS issues are the greatest significance for building of political mutual trust and make the SCS become a sea of peace, friendship and cooperation through joint efforts with ASEAN under the preventive diplomacy. In 2016, ASEAN-China's cooperation on the SCS had fruitful outcomes over unexpected by adopted the ASEAN-China Joint Statement on the Full and Effective Implementation of the DOC in the SCS in Lao PDR (ASEAN, Joint Statement of 
the Foreign Ministers of ASEAN Member States and China on the Full and Effective Implementation of the Declaration on the Conduct of Parties in the South China Sea, 2016).

\section{The Progressing of the Code of Conduct (COC)}

The SCS has been a popular political and security issues in dialogue relations between ASEAN and China. Many outcome documents such as Joint Statements, Press Statements, Joint Communiques, Declarations, especially Chairman's Statements of ASEAN Leaders always took into accounts to be concerned on the SCS issues, which mentioned almost in the higher-level meetings. The SCS discussions always appeared in ASEAN Senior Official's Meeting (SOM), ASEAN Foreign Minister's Meetings (AMM), ASEAN-China Summit, and ASEAN Summit and Related Summits, ARF, EAS, and APT. The DOC was the most important political instruments between ASEAN-China that made tension in the SCS become much positive and effective which has been resulted by the negotiation mechanism and preventive diplomacy. The revolutions of the DOC were absolutely progressing, and ASEAN's preventive diplomacy incorporated with China have been taken action to deeply solve the issues by the development on the COC. The COC is a share rules and norms for responsibilities regarding a set of rules outlining to properly practices for an individual, parties, or organizations, and the COC was agreed by ASEAN and China to set up during the 2002 Summit (South China Sea Morning Post, What Is the South China Sea Code of Conduct, and Why Does It Matter?, 2017).

Progressing the COC noticeably sought to the consultation between ASEAN and China with their willingness to finalize whether it was a legally binding or non-legally binding. The $\mathrm{COC}$ is sharpened more specific to dispute resolving than the DOC. Raising a major concerned, the COC could be such a political tool for China to further take more actions in the SCS by legitimating its activities to engage in real practicing. In addition, China may use the $\mathrm{COC}$ as preventive diplomacy to prevent on any decision making in ASEAN regarding the SCS issues, and sometime China can be avoided the criticism while claiming its territory in the SCS (Thu, 2018).

In fact, in 2017, ASEAN-China reached to the adoption on the framework of the COC, which reflected the roles of ASEAN's preventive diplomacy in preventing disputes in the SCS. This framework aims to establish a rules-based framework containing a set of norms to guide the conduct of parties and promote maritime cooperation in the SCS and mutual trust, cooperation and confidence, prevent incidents, manage incidents should they occur, and create a favorable environment for the peaceful settlement of the disputes, and especially to ensure maritime security and safety, and freedom of navigation and overflight (ASEAN, Chairman's Statement of the ASEAN Post Ministerial Conference (PMC) 10+1 Sessions with the Dialogue Partners, 2017). China always encouraged the claimant states to solve the dispute over territory and sovereignty in the SCS by parties directly concerned without the threat or use of force in accor- 
dance with the universally recognized principles of the international laws and 1982 UNCLOS, in order to the maintain the regional peace and stability that was the improve tool and essential for China's development. Nevertheless, if the third parties get involved in bilateral issues, it would be made the issue more complicated and cannot be addressed or resolved in peaceful manner.

The official negotiation on the COC has been proceeded in spirit of cooperation and understanding, to foster dialogue and encourage discussions on practical maritime cooperation which would be shared contribution to peace, security, stability and sustainable development in the SCS, as well as to build more trust and confidence between AMS and China. In this connection, the most important section in the $\mathrm{COC}$ is the Principles Section that divided into four parts. First principle is that the $\mathrm{COC}$ is "Not an instrument to settle territorial disputes or maritime delimitation issues." The second principle is "Commitment to the purposes and principles of the Charter of the United Nations, the 1982 UNCLOS, the Treaty of Amity and Cooperation in Southeast Asia (TAC), the Five Principles of Peaceful Coexistence, and other universally recognized principles of international law". The third principle is "Commitment to full and effective implementation of the DOC", and the fourth is "Respect for each other's independence, sovereignty and territorial integrity in accordance with international law, and the principle of non-interference in the internal affairs of other states" (Ian, 2017). ASEAN and China reaffirmed their commitment to the full and effective implementation of the DOC and the early conclusion of the COC must be based on consensus.

To conclude, ASEAN consumes the preventive diplomacy to preclude the SCS issue between China and dispute parties of AMS; therefore, the DOC and the COC that constructed by ASEAN-China was proved the successfully of the ASEAN's preventive diplomacy on disputes settlement.

\section{Applied ASEAN's Preventive Diplomacy in the Rakhine State}

The Rakhine State is located in Western part of Myanmar, which is the historically home of most of Muslim people and known as Rohingyas, and they are claiming self-identify from Myanmar government. Rohingyasis the most challenge issues about refugees in the world that the restriction has been taken place regarding the legal and social discrimination. Rohingyas, the ethnic minority was a subject to be categorized and limited people's rights by Myanmar's government, and people cannot travel without permission and outside working prohibited, and they also cannot marry without authorization especially lacking of getting opportunity to medical care and education (EU, 2018). Rohingyas population is declined the given citizenship under the 1982 Myanmar nationality law, and it has been challenged military crackdowns in 1978, 1991-1992, 2012, 2015 and 2016-2017, and based on the report of the United Nation and Human Rights Watch as investigator to Myanmar stated that Myanmar wanted to expel 
the whole Rohingyas population (Md Islam, Saha, \& Md, 2017). From 25 August 2017 to 22 October 2017, approximately 603,000 Rohingya refugees from Rakhine State had escaped crossed the border into the Bangladesh, and it was rapidly increased to 624,000 refugees by 7 November 2017 (EU, 2018). The agreement between the government of Myanmar and Bangladesh reached in January 2018, in order to repatriate 156,000 Rohingyas for over two years; however, this agreement was discussed under international law (Kaitin \& Brenda, 2018). Recently in November 2018, numerous Rohingyas's repatriation reached 700,000, which steadily increased and caused the situation more concerns and serious (Mayuko, 2018).

ASEAN's principles are shared values and norms in order to maintain and enhance peace, security and stability and strengthen peace-oriented valued in the region (ASEAN Charter, 2011). In this connection, Myanmar's Rohingyas issues is concerned by ASEAN Leaders because it is the challenge internal issues which made ASEAN faced obstacles to keep peace and security in the Southeast Asia region. Among 10 members of ASEAN, only a few countries such as Thailand, Malaysia, and Indonesia had conveyed their impression to accept the Rohingyas as temporary settlers in their territories, and Malaysia was the one who needed Rohingyas because of cheaper labor. Moreover, during the 26th ASEAN Summit in Kuala Lumpur and Putrajaya, Malaysia, Thailand and Indonesia Foreign Ministers' meeting decided to provide them with temporary shelter, food and medicine, and then a Joint Statement has been released regarding the given humanitarian assistance on a temporary to 7000 stranded people (Kundu, 2015).

Malaysian Prime Minister, Najib Razak, on 4th December 2016, was concerned on Myanmar's genocide of the Rohingyas, and during ASEAN Foreign Minister's meeting, Malaysian Foreign Minister, Excellency Anifah Aman underscored the situation of Rohingyas as a regional concern and should be resolved together-ASEAN shouldn't ignore to this crisis due to we are on the same boat, so an urgent mechanism must be determined. In this regard, Indonesian President Joko "Jokowi" Widodo also discussed on the Rohingyas issues with Aung San Suu Kyi, State Counselor of Myanmar, that the Rohingya crisis was the most important not only for Myanmar but also for the whole region (Lego, 2017). Regarding the high tensions on Rohingyas crisis, ASEAN's preventive diplomacy has been played as a crucial role by encouraging Myanmar to draw much attention on solving by peaceful means. At the 30th ASEAN Summit in 2017, ASEAN issued a statement on the establishment a task force to respond to "crisis and emergency situations rising from irregular movement of persons in Southeast Asia", and this statement was referred to the following up the Rohingyas (Lee, 2018). At the sideline of ASEAN Foreign Minister's Meeting interface with the United Nations General Assembly, both parties expressed the "grave concern with these alleged acts of violence" on the Rohingyas crisis (Boyle, 2018). ASEAN also has been trying to promote the awareness to ASEAN people, which regarded the promotion and protection of human rights and specifically on the migrant workers. As the 
Rohingyas crisis is related to the human rights, and ASEAN also has one body concerned about human rights namely, the ASEAN Intergovernmental Commission on Human Rights (AICHR), but this ASEAN body was limited its obligations as enshrined in its Term of References (TOR)-non-interference in the internal affairs of ASEAN Member States-so it was just encouraging Myanmar government to promote and protect human rights (ASEAN Secretariat, Term of Reference: ASEAN Intergovernmental Commission on Human Rights (AICHR), 2014). On 24 September, ASEAN Foreign Ministers issued a statement expressed on the development in the Northern Rakhine State that the Rohingyas against Myanmar security force, which resulted in suffering of the loss of so many civilian lives, homeless, no shelter, and starvation (ASEAN, ASEAN Chairman's Statement on the Humanitarian Situation in Rakhine State, 2017). Regarding to this, Foreign Ministers denounced to all relevant parties to prevent these kinds of actions that could be impacted to the worsen situation and belief that the major causes of this crisis must be found-the ministers fully encouraged Myanmar and Bangladesh to take closer dialogue in cooperated with ASEAN. This statement reflected the practice of the preventive diplomacy in preventing conflicts. Of course, the 13th EAS underscored the progress of peaceful settlement of the Rohingyas crisis that relevant parties-the JWG meeting between the government of Myanmar and Bangladesh are working very active-have high commitment to ensuring safety and security of returning displaced persons to Myanmar based on the full implementation of their agreement under the ASEAN's umbrella (ASEAN, Chairman's Statement of the 13th East Asia Summit, 2018). As a result, ASEAN's preventive diplomacy would be defined by ASEAN's continuing supports on Myanmar's efforts in engaging peace, stability, and enduring respect the rule of law by maintaining the equitable development with widespread violence. In contrast, the problem is that the Myanmar government does not recognize Rohingyas as occupants of the Rakhine State, and ASEAN is quietly difficult to implement the ASEAN-led mechanism. ASEAN countries concerned this issue and it should be the government of Myanmar settles by preventing the migration of the Rohingyas to the bordering countries such as Indonesia and Malaysia, and the bordering countries. Finally, these countries reached the agreement to accept the Rohingyas with temporary relief (Kundu, 2015).

ASEAN has so many supporting centers in different functions based on the needs of each pillar, and among of those centers, the ASEAN Coordinating Centre for Humanitarian Assistance on disaster management (AHA Centre) is an intergovernmental organization that established by ASEAN on 17 November 2011. The AHA Center is working to facilitate cooperation and coordination on disaster management and emergency response in ASEAN, and its actions are well cooperated with the United Nations, Private Sectors, Civil Society Organization, Red Cross and Red Crescent Movement, other international organizations and especially with the national disaster management organizations inside 
AMS and ASEAN dialogue partners (The AHA Center, One ASEAN One Response, n.d.). In this regard, the Royingyas crisis happened in the Rakhine State, Myanmar-this called the emergency response in ASEAN because many refugees have been displaced and need a lot of humanitarian assistance, so ASEAN must take over actions through AHA Center. At the 33rd ASEAN Summit in Singapore, ASEAN leaders discussed about the Rakhine State issue and opened the floor for Myanmar government to brief situation, and the ASEAN Leaders encouraged both parties-the Joint Working Group meeting between Bangladesh and Myanmar-to start the repatriation of displaced persons to Myanmar, and ASEAN is fully ready to support and cooperate between Myanmar and the AHA Center team in the repatriation process (ASEAN, Chairman's Statement of the 33rd ASEAN Summit, 2018). In addition to this, ASEAN Leaders satisfied with the signed MOU between Myanmar and United Nations Development Programme (UNDP) and the United Nations High Commissioner for Refugees (UNHCR), and stand ready to see the implementation of these parties regarding the process of the repatriation process of displaced persons. ASEAN would like Myanmar government to find the best and comprehensive solution to deal with the causes of conflicts and avoid the widespread into violence through diplomacy-encourage Myanmar for its utmost efforts to building peace, stability, cooperated with various community, respected the rule of law, and tried to maintain the conducive environment in the Rakhine State. The preventive diplomacy has been practiced through the agreement between Myanmar and Bangladesh joint working group and the MOU. More importantly, a good bilateral cooperation between Myanmar and Bangladesh and with the help of international community, Myanmar would be able to bring peace, stability, and equitable development in order to promote social harmony and national reconciliation among the various communities in Rakhine State.

To the above-mentioned subjects, to what extent ASEAN responded to these problems regarding the human rights and refugees crisis. In fact, ASEAN's preventive diplomacy plays a crucial role to negotiate with all relevant parties especially the relationship between Myanmar and Bangladesh. The roles of ASEAN members, Malaysia, Indonesia, and Thailand, have been actively involved in the constructive building peace in order to the promotion and protection of human rights-ASEAN would be used to its own mechanism such preventive diplomacy to prevent all conflicts disputes and facilitate with disputes parties by practicing the peaceful settlement through diplomacy or international law; whereas, ASEAN welcomed all dispute parties especially ASEAN members to advance exercise with non-violence conflicts and implement the preventive diplomacy as priority procedure due to ASEAN's principles-non-interference into internal affairs of AMS and others (ASEAN Charter, 2011).

\section{Conclusion}

After Southeast Asia's rises, the formation of ASEAN was officially established in 1967; therefore, the preventive diplomacy had been forwards and actively stand- 
ing as the international norms building, confidence building efforts, enhancing channels of communication, and active role by the ARF chair, to prevent and minimize conflicts by nation states.

In this connection, the roles of the preventive diplomacy have been activated and fashionable in negotiating among ARF members' disputes and also with dialogue partners or relevant stakeholders, and the best example shown off in the meetings of the ARF, EAS, and APT in which all major powers join and discuss peace and security always. Many concern issues have been discused through ASEAN meetings, and most outcomes were appreciated and noted with satisfaction by all parties because of consensus principle.

Generally, the preventive diplomacy appeared in the SCS issues that is a very sensitive dispute between China and the most relevant states in ASEAN-Viet Nam, the Philippines, Malaysia, and Brunei. Regarding to this, ASEAN's dispute settlement mechanism is actively involved in the negotiation among the claimant states by the preventive diplomacy. The successfully of ASEAN's preventive diplomacy reflected through the signed DOC by the Foreign Ministers of AMS and China in Phnom Penh, and the progressing of COC, which presented two main aspects. One is the confirmation of peaceful resolution of territorial disputes, without resorting to the threat or use of force, through friendly consultations and negotiations by sovereign states directly concerned. The other is the enhancement of confidence building and promoting trust through mutual exchanges and undertaking projects and activities in practical maritime cooperation in the SCS, and also the development on the COC to be finalized soon. Moreover, the case of the Rohingyas crisis is a also key challenge issue for regional concerns and international issues, in which Myanmar and Bangladesh government have been working closely especially with Thailand, Malaysia, Indonesia, and other AMS through the intervention of the ASEAN's preventive diplomacy. Due to ASEAN's principles is to promote and protect human rights, so ASEAN always encouraged Myanmar government to elaborate this crisis based on the international human rights system; even ASEAN couldn't directly interfere; but ASEAN has discussed to find the best resolution in order to keep peace and harmony ASEAN regions; the AICHR and AHA Center stand ready to facilitate with the process of repatriation of displaced persons and encourage both parties to uphold with the preventive diplomacy. The preventive diplomacy could be found as an agreement between Myanmar and Bangladesh in 2018 to further discuss on Rohingyas crises under the international law especially the acceptance of Rohingyas to Thailand, Malaysia, and Indonesia, as temporary shelters, and especially the signed MOU between Myanmar and UNDP and UNHCR.

ASEAN's preventive diplomacy could be defined as win-win strategy to prevent conflicts and mainstream a very substantial diplomacy tie in order to improve state relations with relevant actors to come up with peace building and security in the region. 


\section{Acknowledgements}

First, I would like to pay my highest respects and profound thanks to my respectful Parents for the motivation, encouragement and stayed at my sides always. I also thanks to the Central China Normal University, which provided a precious opportunity for me to pursue my $\mathrm{PhD}$ in International Politics. Regarding to this article, I particularly thanks to Professor Zhao Changfeng for his excellence advices and guidance. Lastly, I would like to thank to all my friends who motivated, supported, and encouraged me to write down this article.

\section{Author}

Mr. Chheun Sokla is a Cambodian who is currently perusing his Doctor's Degree in International Politics at the School of Politics and International Studies, China.

\section{Conflicts of Interest}

The author declares no conflicts of interest regarding the publication of this paper.

\section{References}

ASEAN (2001). 2001 ASEAN Regional Forum: Concept and Principles of Preventive Diplomacy. https://cil.nus.edu.sg/wp-content/uploads/2019/02/2001-ARF-CONCEPT-AND-PRIN CIPLES-OF-PREVENTIVE-DIPLOMACY.pdf

ASEAN (2002). The Declaration on the Conduct of Parties in the South China Sea (DOC). Phnom Penh.

ASEAN (2011). ASEAN Charter.

ASEAN (2012). ASEAN Protocol on Enhanced Dispute Settlement Mechanism.

ASEAN (2013). Chairman's Statement of the 16th ASEAN-China Summit. Bandar Seri Begawan.

ASEAN (2013). Chairman's Statement of the ASEAN Post Ministerial Conference (PMC) $10+1$ Sessions with the Dialogue Partners. Bandar Seri Begawan.

ASEAN (2014). Chairman's Statement of the 17th ASEAN-China Summit. Nay Pyi Taw.

ASEAN (2016). Joint Statement of the Foreign Ministers of ASEAN Member States and China on the Full and Effective Implementation of the Declaration on the Conduct of Parties in the South China Sea. Vientiane.

ASEAN (2017). ASEAN Chairman's Statement on The Humanitarian Situation in Rakhine State.

https://ASEANorg/asean-chairmans-statement-on-the-humanitarian-situation-in-rakh ine-state

ASEAN (2017). Chairman's Statement of the ASEAN Post Ministerial Conference (PMC) $10+1$ Sessions with the Dialogue Partners. Manila.

ASEAN (2017). Joint Communique of the 50th ASEAN Foreign Ministers' Meeting. Manila.

ASEAN (2018). Chairman's Statement of the 13th East Asia Summit. Singapore.

ASEAN (2018). Chairman's Statement of the 21st ASEAN plus Three Summit. Singapore. 
ASEAN (2018). Chairman's Statement of the 25th ASEAN Regional Forum. Singapore: Association of Southeast Asian Nations.

ASEAN (2018). Chairman's Statement of the 33rd ASEAN Summit. Singapore.

ASEAN Regional Forum (n.d.). ASEAN Secretariat (2011). Surin to Thailand and Cambodia: "Let ASEAN Help Mediate Soonest".

ASEAN Secretariat (2014). Term of Reference: ASEAN Intergovernmental Commission on Human Rights (AICHR).

ASEAN Secretariat (2018). Overview of ASEAN plus Three Cooperation. https://ASEANorg/storage/2017/06/Overview-of-APT-Cooperation-Jun-2017.pdf

Basu, R. (2012). International Politics: Concepts, Theories and Issues. Singapore: Sage Publications India Pvt. Ltd.

Bern (2008). ABC of Diplomacy. Swiss Federal Department of Foreign Affairs (FDFA).

Boyle, D. (2018). ASEAN Talks Tough on Rohingya Crisis. Voice of America (VOA). https://www.voanews.com/a/asean-talks-tough-rohingya-crisis/4601349.html

Breckon, L. (n.d.). China-Southeast Asia Relations: A New Strategic Partnership Is Declared (p. 4).

Cossa, R. A. (2002). Promoting Preventive Diplomacy in the Asia Pacific Region. In CSCAP (Ed.), Preventive Diplomacy: Charting a Course for the ASEAN Regional Forum (Vols. 3-02, p. 1). Honolulu, HI: Pacific Forum CSIS.

CSCAP (1999-2018). Council for Security Cooperation in the Asia Pacific. http://www.cscap.org

East Asia Summit Factsheet (2018). Australian Government: Department of Foreign Affairs and Trade.

https://dfat.gov.au/international-relations/regional-architecture/eas/Documents/eas-fa ctsheet.pdf

East Asia Summit Factsheet (n.d.). Australian Government: Department of Foreign Affairs and Trade.

https://dfat.gov.au/international-relations/regional-architecture/eas/Pages/east-asia-su $\underline{\text { mmit-eas.aspx }}$

EU (2018). ECHO Factsheet: The Rohingya Crisis. European Commission: European Civil Protection and Humanitarian Aid Operations.

Friedrichs, J. (2012). East Asian Regional Security. Asian Survey, 52, 754-776. https://doi.org/10.1525/as.2012.52.4.754

http://home.sogang.ac.kr/sites/jaechun/courses/Lists/b7/Attachments/21/as.2012.52.4.7 54.pdf

Gu, J. F. (n.d.). Dispute Resolution in the South China Sea: From "Joint Development" to "Joint Protection".

Hammarskjöld, D. (2011). Report of Secretary General: Preventive Diplomacy: Delivering Results. New York: United Nations.

Ian, S. (2017). Assessing the ASEAN-China Framework for the Code of Conduct for the South China Sea.

Kaitin, W., \& Brenda, Y. (2018). The Rohingya Crisis Making the Transition from Emergency to Longer Term Development. HPG Humanitarian Policy Group. http://www.odi.org.uk/hpg

Keating, C. (2011). Security Council Report: Update Report. New York: Security Council. http://www.securitycouncilreport.org

Kesavapany, K. (2011). ASEAN and the Cambodia-Thailand Conflict. Institute of South- 
east Asian Studies.

https://www.eastasiaforum.org/2011/03/01/asean-and-the-cambodia-thailand-conflict

Kevin, H. R. V., \& Rosariom, G. M. (2017). ASEAN Consensus: The Intangible Heritage of Southeast Asia Diplomacy. Building ASEAN Community: Political-Security and Socio-Cultural Reflections, 4, 88.

Kishore, M., \& Jeffery, S. (2017). The ASEAN Miracle: A Catalyst for Peace. Singapore: Ridge Books, The National University of Singapore.

Kundu, S. (2015). The Rohingyas: Security Implications for ASEAN and beyond. IDSA Issue Brief.

Lee, H. Y. (2018). ASEAN's Limited Role in Solving the Rohingya Crisis. The Diplomat. https://thediplomat.com/2017/05/why-asean-cant-ignore-the-rohingya-crisis

Lego, J. (2017). Why ASEAN Can't Ignore the Rohingya Crisis. The Diplomat. https://thediplomat.com/2017/05/why-asean-cant-ignore-the-rohingya-crisis

Mancini, F. (2011). Preventive Diplomacy: Regions in Focus. New York: International Peace Institute.

Martin, G., Terry, O., \& Steven, C. R. (2008). International Relations: The Key Concepts (Second Edition ed.). New York: Routledge.

Mayuko, T. (2018). ASEAN Aims to Express “Concern" on Rohingya Crisis for First Time. Nikkei Asian Review.

https://asia.nikkei.com/Politics/International-relations/ASEAN-aims-to-express-conce rn-on-Rohingya-crisis-for-first-time

Md Islam, S., Saha, F., \& Md, T. N. (2017). Rohingya Crisis and the Concerns for Bangladesh. International Journal of Scientific and Engineering Research, 8, 1.

http://www.ijser.org

Mitchell, S. (2016). Territorial Disputes. Oxford Bibliographies.

http://www.oxfordbibliographies.com/view/document/obo-9780199743292/obo-97801 99743292-0178.xml

Müllerleile, A. (n.d.). EIP Explainer: What Is "Preventive Diplomacy"? EIP European Institute for Peace.

http://eip.org/en/news-events/eip-explainer-what-\%E2\%80\%98preventive-diplomacy\% E2\%80\%99

Nick, B. (2017). The East Asia Summit and ASEAN: Potential and Problems. Contemporary Southeast Asia, 39, 265-272. http://www.jstor.org/stable/44683768

Quilop, R. J. (2002). Moving toward Preventive Diplomacy: Challenges and Prospects for the ARF. In CSCAP (Ed.), Preventive Diplomacy: Charting a Course for the ASEAN Regional Forum (pp. 17-18). Honolulu, HI: Pacific Forum CSIS.

Ralf, E., \& See, S. T. (2009). ASEAN Regional Forum and Preventive Diplomacy: A Failure in Practice (pp. 159, 5).

Sharp, P. (2009). Diplomatic Theory of International Relations. New York: University of Minnesota; Duluth, MN: Cambridge University Press.

South China Sea Morning Post (2017). What Is the South China Sea Code of Conduct, and Why Does It Matter?

https://www.scmp.com/news/china/diplomacy-defence/article/2105190/what-south-ch ina-sea-code-conduct-and-why-does-it

Thayer, C. A. (2013). ASEAN: China and the Code of Conduct in the South China Sea. https://muse.jhu.edu/article/527061/pdf

The AHA Center (n.d.). One ASEAN One Response. https://ahacentre.org 
Thu, H. L. (2018). Asia Maritime Transparency Initiative.

UN News (2013). UN Court Rules for Cambodia in Preah Vihear Temple Dispute with Thailand.

https://news.un.org/en/story/2013/11/455062-un-court-rules-cambodia-preah-vihear-t emple-dispute-thailand

Yuzawa, T. (2006). The Evolution of Preventive Diplomacy in the ASEAN Regional Forum: Problems and Prospects. Asian Survey, 46, 785-804.

https://doi.org/10.1525/as.2006.46.5.785

Zyck, S. A., \& Muggah, R. (2012). Preventive Diplomacy and Conflict Prevention: Obstacles and Opportunities, Stability. Stability: International Journal of Security and Development, 1, 68-75. https://doi.org/10.5334/sta.ac 